\title{
ICE FABRICS IN A VERTICAL FLOW PLANE, BARNES ICE CAP, CANADA
}

\author{
By Roger LeB. Hooke and Peter J. Hudleston
}

\author{
(Department of Geology and Geophysics, University of Minnesota, Minneapolis, \\ Minnesota 55455, U.S.A.)
}

\begin{abstract}
At a depth of about $75 \mathrm{~m}$ in the lower part of the accumulation area of the Barnes Ice Cap there is a change from fine-grained ice with a weakly-oriented $c$-axis fabric to coarser ice with a broad single-maximum fabric. At a depth of about $150 \mathrm{~m}$ the single maximum becomes elongate perpendicular to the direction of bubble elongation, and then splits into two distinct maxima making an angle of about $40-45^{\circ}$ with respect to one another. At greater depths a third and finally a fourth maximum appear, forming the well known diamond pattern. Mean crystal size does not seem to increase in the transitions from one to two and thence to three maxima, but it may become more uniform. Crystal size does increase in the transition from three to four maxima, however. At the base of the glacier there is a $10-20 \mathrm{~m}$ thick layer of unusuallybubbly, fine-grained white ice with a strong single-maximum fabric.

The depths to the transitions increase up-glacier and in place of the single-maximum fabric a small-circle pattern is found. Down-glacier the depths to the transitions decrease, systematically eliminating the higher zones. Thus in the lower part of the ablation area, ice with a four-maximum fabric appears at the surface.

The independent variables governing these fabric transitions appear to be temperature $T$, stress $\tau$, and cumulative strain $\bar{\gamma}_{\mathrm{oc}}$. In a tentative stability diagram showing the fields in which given fabrics are stable in $T-\tau-\bar{\gamma}_{\mathrm{oc}}$ space, multiple-maximum fabrics occur at high temperatures $\left(>-10^{\circ} \mathrm{C}\right)$ and at moderate to high stresses, weakly-oriented fabrics at low stresses or low cumulative strains, broad single-maximum fabrics at moderate stresses or moderate cumulative strains, and strong single-maximum fabrics at high stresses or large cumulative strains.
\end{abstract}

RÉsumé. Structure cristalline de la glace dans une coupe verticale de l'écoulement, Barnes Ice Cap, Canada. A une profondeur d'environ $75 \mathrm{~m}$ dans la partie inférieure de la zone d'accumulation du Barnes Ice Cap, on constate un changement de la glace à grains fins avec une orientation faible des axes- $c$ vers une glace plus grossière avec une cristallisation à un seul large maximum. A une profondeur d'environ $150 \mathrm{~m}$, le maximum unique devient allongé perpendiculairement à la direction de l'allongement des bulles, et se divise en deux maximums distincts faisant entre eux un angle d'environ 40 à $45^{\circ}$. A des profondeurs plus grandes, un troisième et finalement un quatrième maximum apparaît formant la structure bien connue en losange. La taille des cristaux s'accroît cependant encore dans la transition de trois à quatre maximums. A la base du glacier, il y a un niveau de 10 à $20 \mathrm{~m}$ d'épaisseur de glace blanche exceptionnellement bulleuse, à grains fins avec une structure à un seul maximum très marqué.

Les profondeurs pour atteindre les transitions décrites croissent en remontant vers le haut du glacier et, à la place de la structure à un seul maximum, on trouve une petite structure circulaire. Vers le bas du glacier les profondeurs jusqu'aux zones de transition décroissent, les zones les plus hautes étant systématiquement éliminées. C'est ainsi que dans la partie inférieure de la zone d'ablation, la glace à quatre maximums apparaît en surface.

Les variables indépendantes réglant ces transitions entre structures semblent être la température $T$, la contrainte $\tau$ et la déformation cumulée $\bar{\gamma}_{\mathrm{oc}}$. Dans un essai de diagramme de stabilité montrant les domaines dans lesquels une structure donnée est stable dans un espace en $T$, $\tau$ et $\bar{\gamma}_{\text {oc }}$, des structures à maximums multiples apparaissent à hautes températures $\left(>-10^{\circ} \mathrm{C}\right)$ et pour des efforts modérés à forts, une structure faible pour des efforts faibles ou de faibles déformations cumulées, des structures à large maximum unique pour des efforts modérés ou des déformations cumulées modérées, et une structure à maximum unique très marqué pour des efforts importants ou de grandes déformations cumulées.

Zusammenfassung. Eisgefüge in einer vertikalen Fliessebene, Barnes Ice Cap, Kanada. In einer Tiefe von etwa $75 \mathrm{~m}$ tritt im unteren Teil des Akkumulationsgebietes des Barnes Ice Cap ein Wechsel von feinkörnigem Eis mit einheitlicher Orientierung der $c$-Achsen zu gröberem Eis mit einem breiten Einzel-Maximum-Gefüge ein. In einer Tiefe von etwa $150 \mathrm{~m}$ dehnt sich das Einzel-Maximum senkrecht zur Richtung der Blasendehnung und spaltet sich dann in zwei getrennte Maxima auf, die einen Winkel von etwa $40-45^{\circ}$ einschliessen. In grösseren Tiefen erscheint ein drittes und schliesslich ein viertes Maximum, das wohlbekannte DiamantMuster bildend. Die mittlere Kristallgrösse scheint beim Übergang von einem zu zwei und dann zu drei Maxima nicht zuzunehmen, doch dürfte sie einheitlicher werden. Beim Übergang von drei zu vier Maxima hingegen wächst die Kristallgrösse. Am Grunde des Gletschers tritt eine 1o-20 m dicke Schicht ungewöhnlich blasenreichen, feinkörnigen weissen Eises mit einem deutlichen Einzel-Maximum-Gefüge auf.

Die Tiefe der Übergangszonen nimmt gletscheraufwärts zu; anstelle des Einzel-Maximum-Gefüges erscheint ein Muster kleiner Kreise. Gletscherabwärts nimmt die Übergangstiefe ab, wobei die höheren Zonen systematisch verschwinden. So erscheint im unteren Teil der Ablationszone Eis mit einem VierMaxima-Gefüge an der Oberfläche. 
Die unabhängigen Variablen, welche diese Gefügeübergänge steuern, scheinen die Temperatur $T$, der Druck $\tau$ und die kumulative Spannung $\bar{\gamma}_{\mathrm{oc}}$ zu sein. In einem versuchsweise konstruierten Stabilitätsdiagramm, das die Felder aufzeigt, in denen gegebene Gefüge im $T-\tau-\bar{\gamma}_{\mathrm{oc}}-$ Raum stabil sind, treten Gefüge mit mehrfachen Maxima bei hohen Temperaturen und bei mässigen bis hohen Drucken, einheitliche Gefüge bei niedrigen Drucken oder niedriger kumulativer Spannung, breite Einzel-Maximum-Gefüge bei mässigen Drucken oder kumulativen Spannungen und deutliche Einzel-Maximum-Gefüge bei hohen Drucken oder grossen kumulativen Spannungen auf.

\section{INTRODUGTION}

Five bore holes have been drilled along a flow line on the Barnes Ice Cap (Fig. I). Temperature and deformation measurements are being made in these holes, and cores were recovered from four of them at depth intervals of 15 to $30 \mathrm{~m}$ for fabric studies. Eight additional cores, referred to as surface samples, were obtained from depths of 0.5 to $\mathrm{I} .5 \mathrm{~m}$ at various locations between the lower three holes.

In this paper we discuss in detail only the core data. Some of the temperature and deformation measurements will be cited where relevant, but analysis of these measurements is not yet complete.

Studies over a period of nearly a decade have yielded a substantial body of data on this flow line. Detailed surface-velocity and surface-strain-rate measurements were made from the divide to the margin between I970 and I97 I (Holdsworth, 1975), and are being repeated along the lower forty per cent of the flow line at present (unpublished data of R. L. Hooke). Ice thickness was determined by radio depth-sounding in 1970 (Jones, I972). Mass-balance measurements were started in 1970 (Holdsworth, 1975) and have been continued up to the present (unpublished data of R. L. Hooke).

The mass-balance data and preliminary analysis of temperature profiles suggest that the equilibrium line is between holes To6r and To8I (Fig. I) (Hudleston and Hooke, in press).

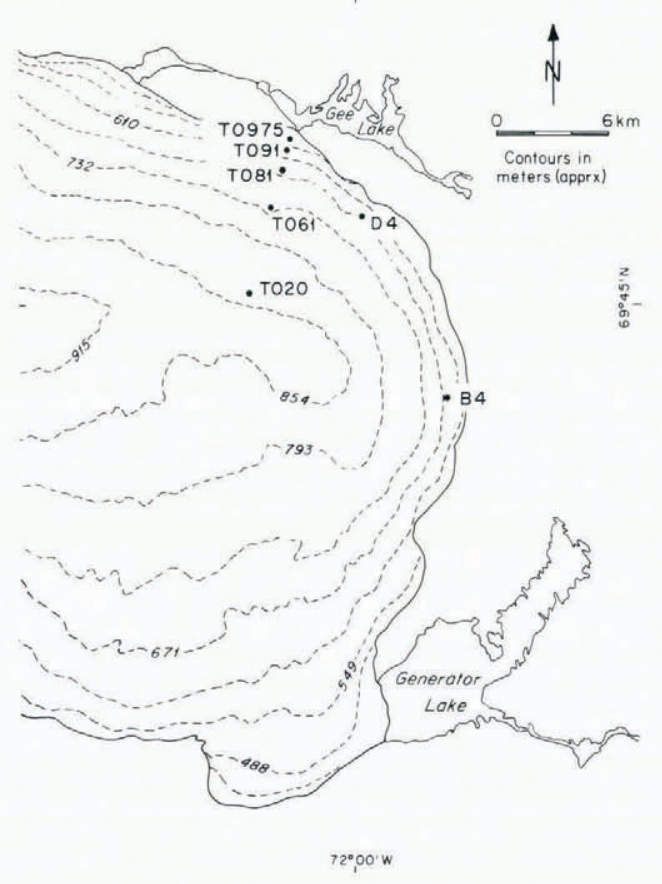

Fig. I. Map of the south dome of Barnes Ice Cap showing bore-hole locations. 


\section{Terminology}

Following Gow and Williamson (I976) we use fabric to refer to the pattern of orientation of $c$-axes, and texture to refer to the size and shape of ice crystals seen in thin section. Actually fabric is not entirely independent of texture as certain textures are always found with the same fabrics. The term cell is used for the two-dimensional figure formed by the intersection of the plane of the thin section with the three-dimensional crystal. In coarse-grained ice two or more cells may be from the same crystal. A particle of ice follows a particle path through time. A flow line or flow plane is a roughly vertical surface, commonly approximately planar, containing one or more particle paths. In an ideal two-dimensional glacier, flow planes would be strictly planar, but in Nature they will invariably deviate somewhat from this ideal.

Bore-hole and surface-sample numbers give the approximate distance of the hole or sample from the divide and the prefix " $\mathrm{T}$ " designates a bore hole. Thus To6r is a bore hole approximately 6.I km from the divide and 0855 is a surface sample approximately $8.55 \mathrm{~km}$ from the divide.

\section{Procedure}

\section{Drilling and coring}

The holes were drilled with an electrical hot point (Hooke, $\left[{ }^{c}{ }_{1976}\right.$ ); a core barrel which was interchangeable with the hot point was used for sampling. The decision to use this procedure rather than continuous coring was dictated by the economics of drill design and of core handling and storage. The hot point makes a $9 \mathrm{~cm}$ hole and the core barrel takes a $6 \mathrm{~cm}$ core with a maximum length of about $0.9 \mathrm{~m}$. Cores are commonly broken into two or three segments upon arrival at the surface, but fracture patterns and bubble elongation usually permit unequivocal realignment of the segments.

\section{Fabric diagrams}

Cores are stored in an ice tunnel excavated in the glacier margin and are studied in a cold laboratory at the end of the tunnel. Temperatures in the tunnel are about $-10^{\circ} \mathrm{C}$ early in the season, but rise to about $-6^{\circ} \mathrm{C}$ by the end of July. Most cores are studied during the season in which they are collected; repeated studies of some of these same cores in subsequent seasons, using both the original and new thin sections, have given no evidence for recrystallization.

Each core is first described, noting bubble concentration and elongation, dirt bands, and foliation. A reference line is then scribed along the core and oriented with respect to the direction of bubble elongation, if any. Finally, thin sections are prepared. Initially most sections were cut perpendicular to the core axis, but in deeper cores which have quite large crystals, sections were also cut either parallel to or at $45^{\circ}$ to the axis. The spacing between thin sections was much greater than the mean cell size in the sections, but in some cases was only slightly greater than the maximum cell size.

Orientations of $c$-axes were measured on a Rigsby universal stage using standard techniques (Langway, I958; Kamb, I962), and the data were plotted in equal-area stereographic projection. All measurements were rotated to horizontal so that a crystal with a vertical $c$-axis in the glacier plots in the center of the net. Diagrams from all sections from a given core were then combined into a single fabric diagram for that core. When thus superimposed, fabric diagrams from successive thin sections in a core with a preferred $c$-axis orientation usually reinforced one another, regardless of the orientation of the thin sections. Thus systematic errors resulting from thin-section orientation, if any, do not appear to be appreciable.

A selection of fabric diagrams is presented in Figures 2, 3, and 4 . Diagrams in Figures 2 and 3 are arranged so that all diagrams from a single bore hole are in the same column, with 

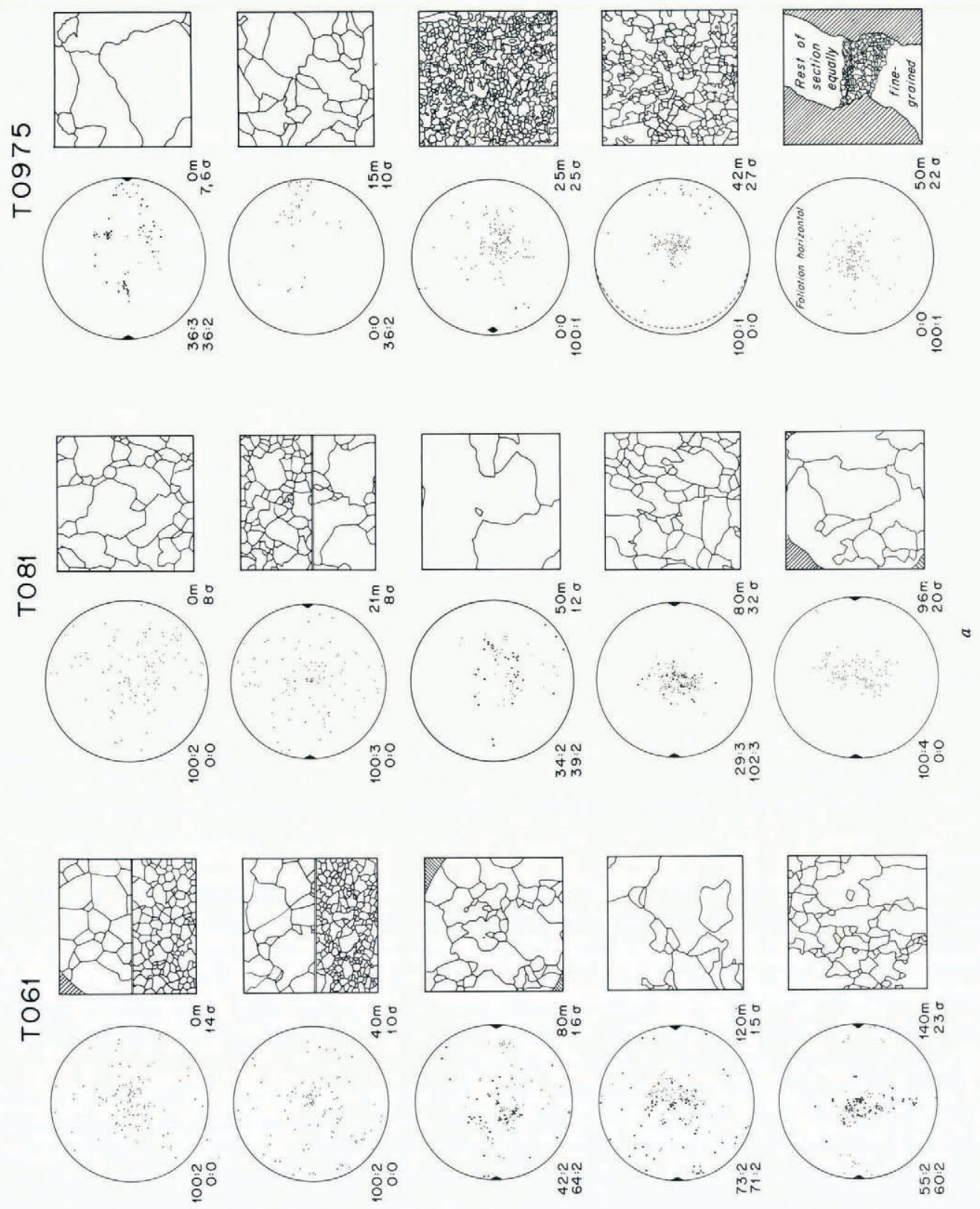

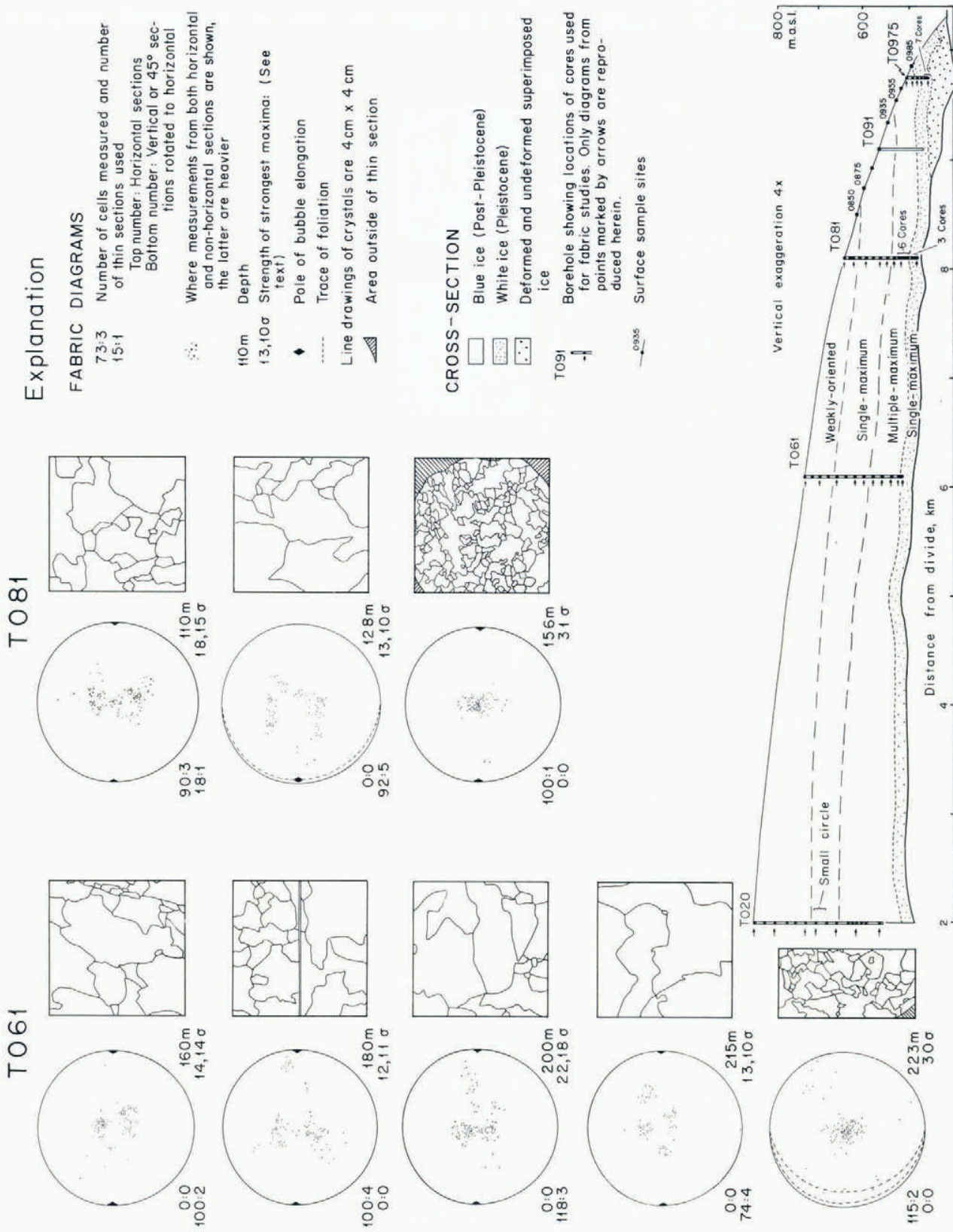

) 
depth increasing down the column and with the direction of flow being from left to right. Not all of the diagrams prepared are reproduced herein, but those not included had patterns which were transitional between those above and below in the bore hole. In Figure 4, the same arrangement is used in the first two columns, but the third column has diagrams from surface sites only. Diagrams in the same row in this figure are from approximately the same particle path.
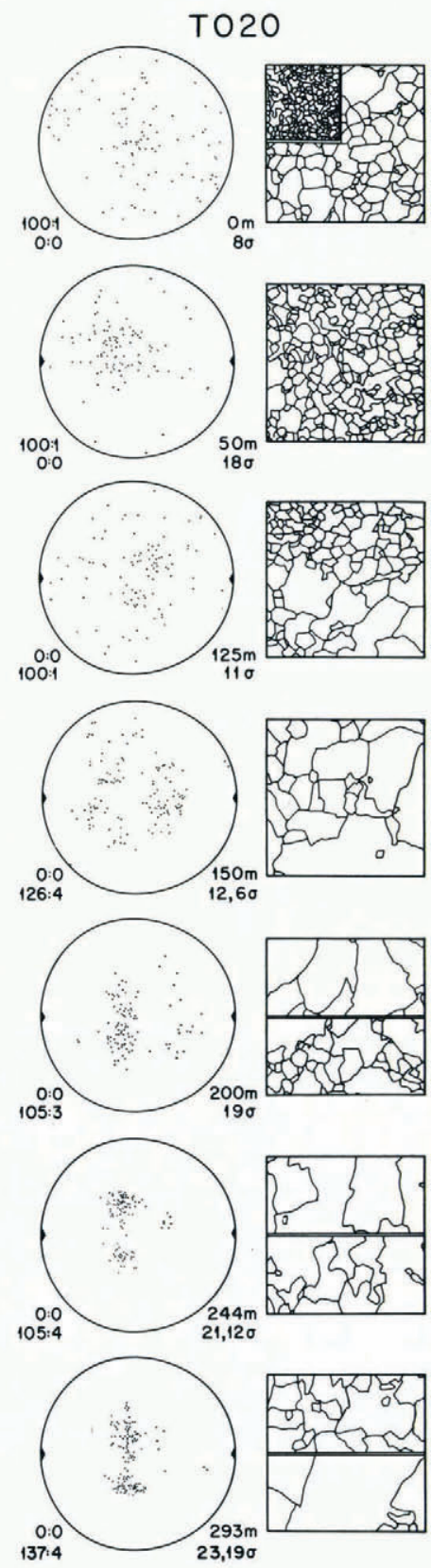

Fig. 3. Fabric diagrams and line drawings of crystal boundaries from cores from hole To2o. For explanation see Figure $2 b$. 

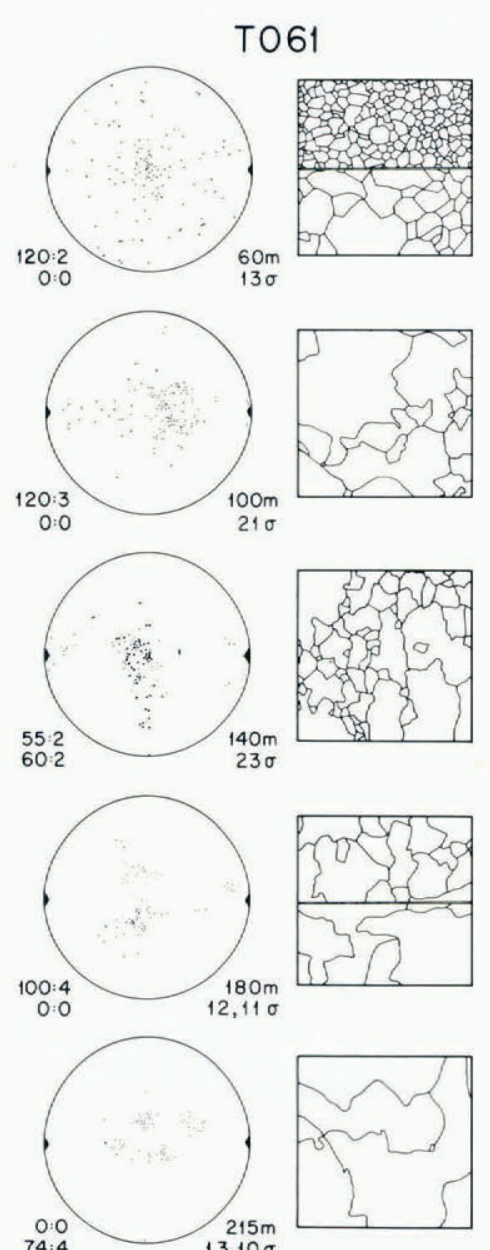
$0: 0$
$74: 4$ $215 \mathrm{~m}$
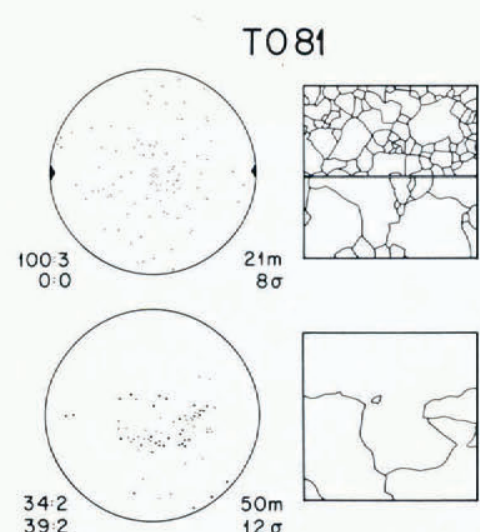

12
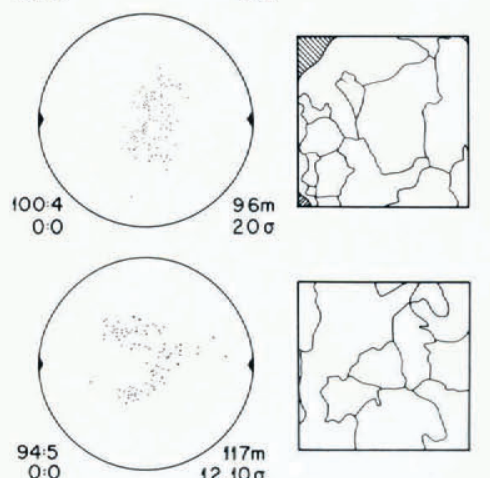

94:5
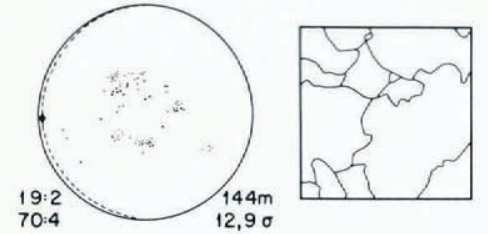

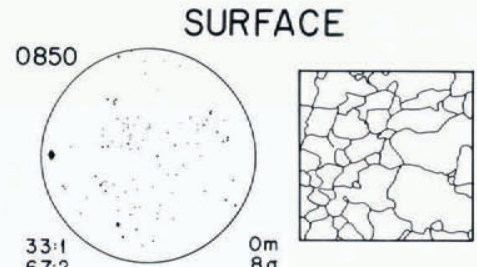

$33: 1$
$67: 2$
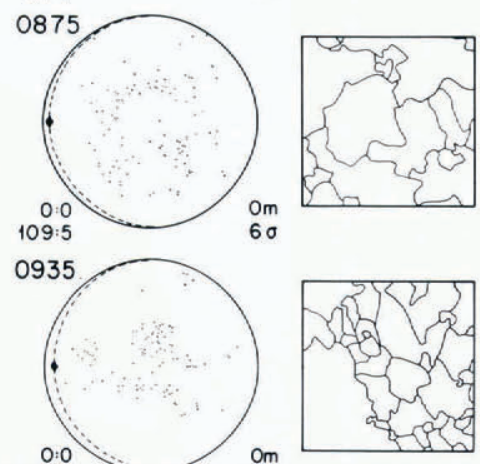

Om

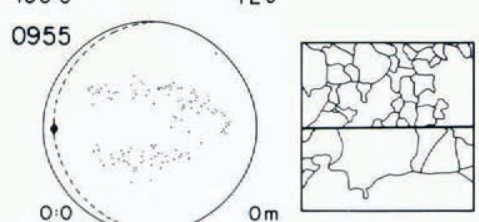

$\stackrel{0 m}{9 \sigma}$ 
In some of the deeper cores the shapes of cells in thin sections are very irregular (Fig. 5) and it is inevitable that some crystals will be represented by two or more cells in a single thin section. By the same token, in ice with a strong preferred orientation of $c$-axes it is quite likely that nearby cells with very similar $c$-axis orientations will, in fact, be from different crystals; for example, cells with a distinct common boundary may have $c$-axis orientations that are nearly identical. Because it is impossible to distinguish between these two possibilities objectively, we have adopted the policy of treating each cell measured as a separate data point, statistically representative of the orientation of the $c$-axis in some volume of ice (Hooke, r969), and points on the fabric diagrams should be interpreted accordingly.

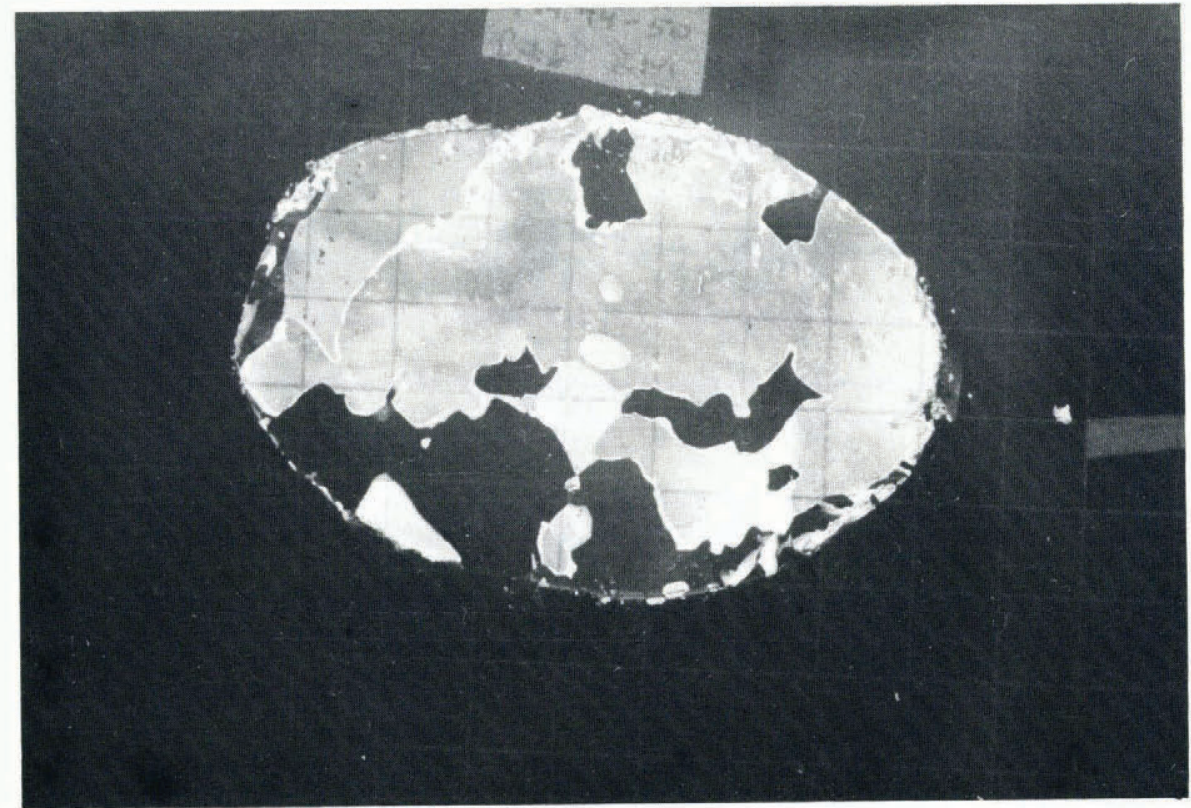

Fig. 5. Photograph of thin section from To81, $144 \mathrm{~m}$. Crossed nicols. Grid spacing is $10 \mathrm{~mm}$. Black cells may all be one crystal.

The percentage of $c$-axes falling in one per cent of the area of an equal-area net is commonly used as a measure of the strength of a fabric. This is not a statistically significant parameter, however (Kamb, I959). Herein we use a method described by Kamb (1959, p. I908-09) in which the number of points in a given sub-area of a fabric diagram is represented by $m+n \sigma$ where $m$ and $\sigma$ are the mean and standard deviation of the number that would be expected in that sub-area if the distribution were random. The value of $n$ for any given sub-area of a diagram is thus a measure of the strength of the fabric. In Figures 2-4 the maximum values of $n$ for each diagram are shown below and to the right of the diagram. Fabrics with $n>3$ are unlikely to represent samples drawn from a random population. By this criterion, none of the fabrics shown is statistically random, but some clearly have stronger preferred orientations than others. It should be noted that the probability of drawing a sample with two or more maxima of roughly equal strength symmetrically disposed about the center of the net is much less than the probability of drawing a sample with a single maximum of similar strength located at random in the net. Kamb's technique evaluates only the latter probability.

Cores taken from the bore holes could not be oriented with respect to the direction of flow. Surface cores could be oriented, however, by taking care not to twist the core barrel when 
retrieving it from the hole. Bubbles in these cores were elongate in a direction approximately parallel to the flow plane and dipped up-glacier. Bubbles observed in tunnels and in vertical shafts which we have dug have also had this orientation (Hooke, 1973; Hudleston, 1977). It is reasonable to assume that the direction of bubble elongation in the deeper cores is likewise parallel to the flow plane, and that where bubbles have a distinct dip, it is in the up-glacier direction. Fabric diagrams in Figures 2-4 are oriented in accord with these assumptions; the direction of bubble elongation is left to right, with the up-dip direction to the left.

In many cores elongate bubbles did not have a distinct dip, so there were two possible orientations. The fabric from 0955 (Fig. 4), an oriented surface core, suggests that where there is a third maximum present it is on the down-glacier side of the diagram. Thus similar three-maximum diagrams from deeper cores have been oriented accordingly.

\section{Crystal size and shape}

Measurements on thin sections may be used to estimate the mean and standard deviation of grain sizes when the texture is isotropic, as is often the case in sedimentary rocks with approximately spherical grains (Krumbein, 1935; Smith and Guttman, I953; Kellerhals and others, 1975). However, the theoretical considerations used for these cases do not apply even approximately to the very irregular interlocking crystals with which we are dealing. Thus we have resorted to three alternative approaches to describe the sizes and shapes of crystals.

First, black and white photographs were taken of all thin sections (Fig. 5) and line drawings were prepared showing crystal boundaries in representative $4 \mathrm{~cm} \times 4 \mathrm{~cm}$ squares in one or more thin sections from each core. These diagrams are reproduced in Figures 2-4. Where cell size varied markedly among thin sections from the same core, $2 \mathrm{~cm} \times 4 \mathrm{~cm}$ drawings from two thin sections are shown (e.g. Fig. 2a, To6r: o m). In black and white photographs, crystal boundaries may be missed when adjacent cells go to extinction at nearly the same orientation;

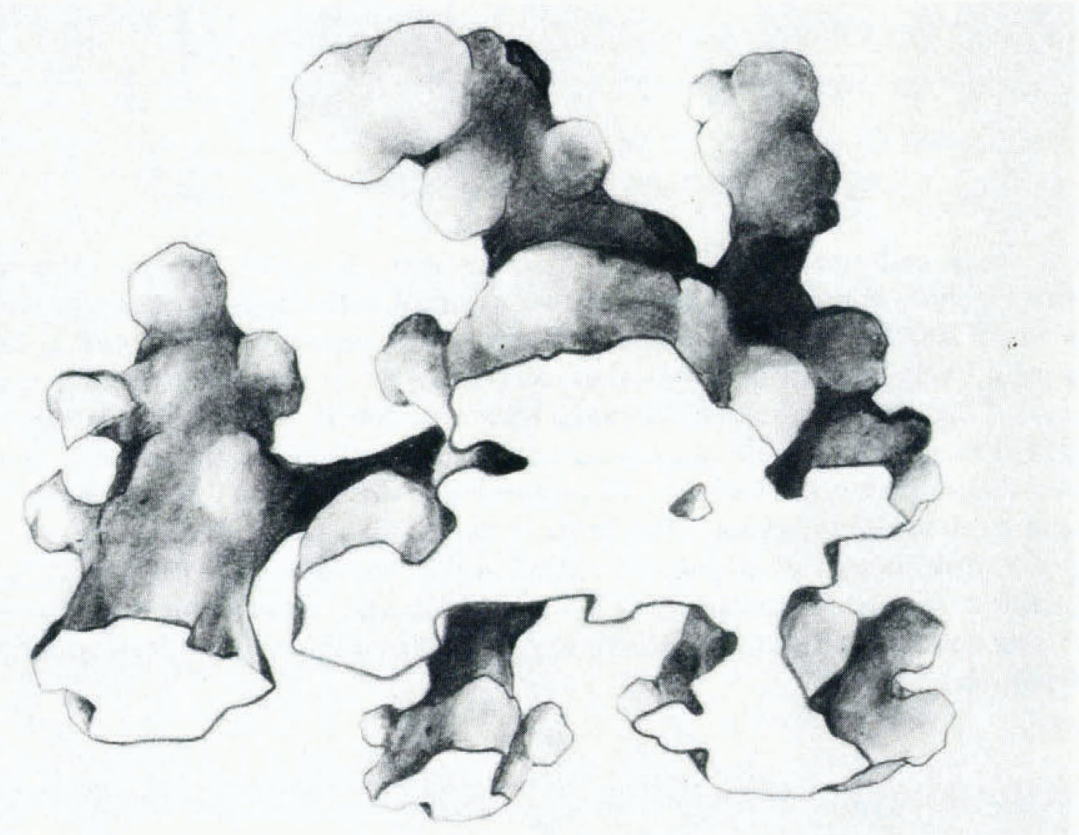

Fig. 6. Sketch of a typical crystal in ice with a multiple-maximum fabric. Based on thin sections. Drawn by R. Venkatakrishnan. 
this is responsible for some of the larger cells in diagrams from the fine ice near the bottoms of the holes (e.g. Fig. 2b, hole To8r : i $56 \mathrm{~m}$ ).

Secondly, from studying the two-dimensional sections we developed a sketch of a typical three-dimensional crystal (Fig. 6).

Finally, following Gow and Williamson (1976), we counted the number of cells in each thin section (or in a representative area of a thin section in fine-grained ice) and divided by the area of the thin section, $A_{i}$, to obtain a mean cell area, $c_{i}$. To then characterize the core the weighted mean cell area $\bar{c}$, was determined, thus

$$
\bar{c}=\sum_{i=1}^{n} c_{i} A_{i} / \sum A_{i}
$$

where $n$ is the number of thin sections from the core. Variations of $\bar{c}$ with depth are plotted in Figure 7. Although we call $\bar{c}$ a weighted mean cell area, its interpretation is not at all clear.

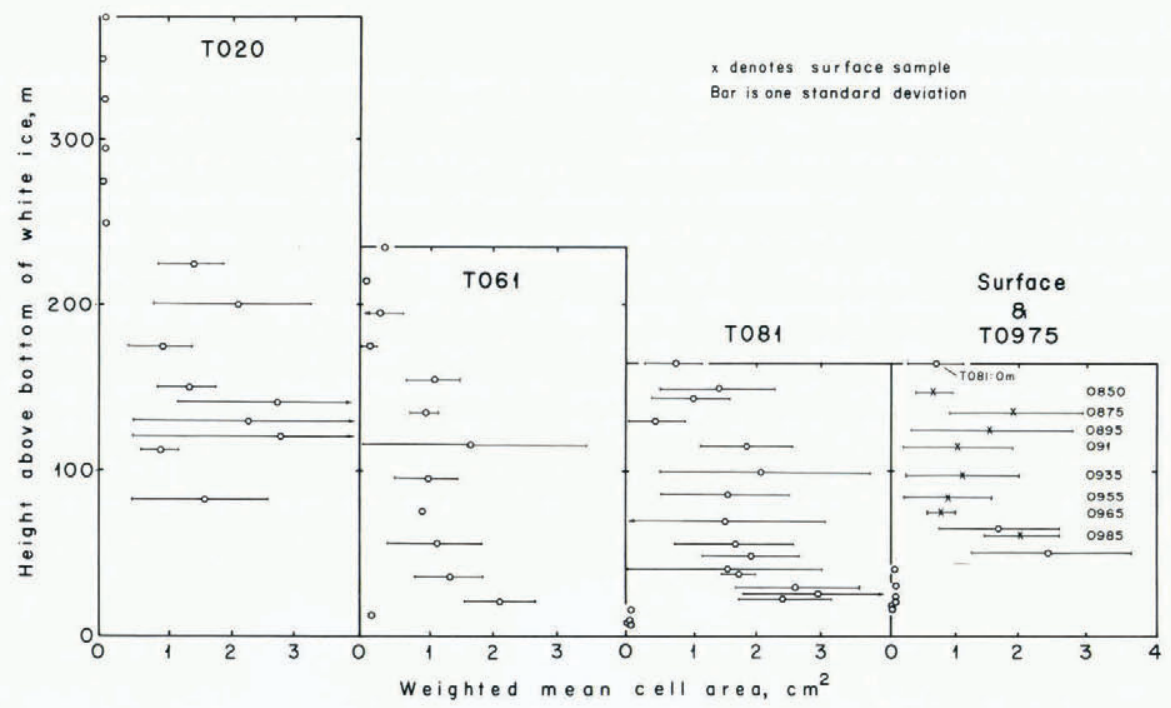

Fig. 7. Weighted mean cell area in bore holes and surface samples.

It is not a mean cell area, particularly in cores with bimodal cell-size distribution as in To6r : o m (Fig. 2a); due to the large number of small cells in such cores the mean cell area would be much smaller. Rather it is an estimate (not rigorous) of the cell area which one would be most likely to find in a new thin section taken at random from the core. Nor are differences in $\bar{c}$ between cores quantitatively accurate. Some of the measurements were made on photographs and thus probably underestimate the number of cells present, particularly in fine-grained ice; conversely cells on the boundaries of a thin section were generally incomplete, thus leading to an underestimate of the areas of these cells, particularly in coarse-grained ice. The results of these biases is to overestimate $\bar{c}$ in fine ice and underestimate $\bar{c}$ in coarse ice. A final problem was the extreme variability in cell size, evident on the line drawings in Figures $2-4$ and in the standard deviation of $\bar{c}$ plotted in Figure 7 , suggesting large variations in crystal volumes.

\section{RESULTS}

The systematic change in fabric with depth is the most obvious variation observed. In hole To6 I (Fig. 2), for example, a weakly-oriented fabric near the surface gives way gradually to a broad single-maximum fabric at a depth of about $75 \mathrm{~m}$. At about $140 \mathrm{~m}$ this single 
maximum becomes elongate transverse to the flow direction, and by $\mathrm{I} 60 \mathrm{~m}$ it has split into a distinct two-maximum pattern. A third maximum appears at $180 \mathrm{~m}$ and a fourth, yielding the infamous diamond pattern, is present at $215 \mathrm{~m}$. Similar fabrics with comparable relative strengths of the maxima and with the same relation to the shear direction, have been observed frequently (Kamb, 1959; Rigsby, I960; Budd, I972; Hooke, 1973; among others). At the base of the glacier a strong single-maximum fabric reappears in a band of white ice. This ice owes its color to a high concentration of air bubbles, making it easily distinguished from the overlying blue ice. Oxygen-isotope studies have suggested that the white ice is of Pleistocene age (Hooke, r 976).

This same pattern of variation in fabric with depth is repeated in the other bore holes and in the surface samples, with minor variations. In To2o, for example, the broad singlemaximum fabric was not found, but a small-circle fabric appears at a depth of $\mathrm{I} 50 \mathrm{~m}$ between the weakly-oriented fabrics above and the elongate single-maximum fabrics below. In To8 I the transition to a broad single-maximum fabric occurs at a depth of about $40 \mathrm{~m}$, and in To975 both the weakly-oriented and single-maximum fabrics are missing. Near the bottom of To8r $(\mathrm{I} 28 \mathrm{~m})$ a peculiar horseshoe pattern is present in ice just above the white ice; normally (To6r, To975, and Hooke, 1973) this ice has the four-maximum fabric.

As noted earlier, the weakly-oriented fabric near the surface is not statistically random; the fabric "strengths" of $8 \sigma$ to I $3 \sigma$ shown (Figs 2-4) are much higher than we could logically expect if the samples were drawn from a population of $c$-axes with truly random orientation, such as might be expected near the surface in the accumulation area. We infer instead that these crystals have grown with a preferred orientation, possibly inherited from flat snow flakes around which the crystals nucleated, or possibly resulting from growth under a temperature gradient. The single-maximum fabrics have "strengths" of I $5 \sigma$ to $25 \sigma$ however, representing a significant increase over those above.

As has been observed previously (Rigsby, I958; Kamb, I959; Hooke, I973; Matsuda and others, 1976; Gow and Williamson, 1976; and others) marked changes in texture accompany the changes in fabric. Ice with weakly-oriented fabrics is generally fine grained $\left(\bar{c}<0.5 \mathrm{~cm}^{2}\right.$, Fig. 7). The change to the broad single-maximum fabric is accompanied by an increase in $\bar{c}$ to $\mathrm{I}-2 \mathrm{~cm}^{2}$, and crystals become intimately interlocked. In ice with two or three-maximum fabrics $\bar{c}$ does not show an appreciable further increase, but there is a possibly significant increase in the minimum size and decrease in the maximum, resulting in a more uniform texture. In ice with four-maximum fabrics $\bar{c}$ increases again, however, to $2-3 \mathrm{~cm}^{2}$. Then in the white ice it decreases to $<0.2 \mathrm{~cm}^{2}$, cells become nearly equant, and the texture is no longer interlocking.

Changes in texture and fabric in the longitudinal direction are much less apparent. Possibly the most significant change is from a small-circle fabric at a depth of $150 \mathrm{~m}$ in To20 (Fig. 3) to a single-maximum fabric at depths of $80 \mathrm{~m}$ in To6 $\mathrm{I}$ and $50 \mathrm{~m}$ in To8 $\mathrm{I}$, and then back to a small-circle fabric at 0875 (Fig. 4).

\section{Strain Modeling}

There is increasing evidence that fabric in ice and other rock-forming minerals is strongly dependent upon cumulative deformation and upon the path by which this deformation is achieved (Kamb, I972; Hudleston, 1977; Hobbs and others, 1976, p. 118-40). It is, therefore, of considerable interest to examine the deformational history of the ice in which the crystallographic fabrics have developed. We cannot do this directly because we do not know the flow history of the ice cap, and there appear to be no objects within the ice that record the total deformation undergone. Instead, we have derived numerically the cumulative strain field in a flow plane of the ice cap assuming a steady-state velocity field and the present surface configuration. The horizontal velocities measured at the surface by Holdsworth (1975) 
are used in this calculation. This velocity is assumed to decrease with depth in accord with a power-type flow law, $\dot{\epsilon}=(\tau / B)^{n}$, with $n=3$ and with $B$ adjusted to give zero velocity on the bed, as temperatures there are below the pressure-melting point. The vertical velocities used are based on long-term mass-balance measurements, adjusted to give a balanced mass budget, and are assumed to decrease linearly with depth. These vertical velocities are somewhat lower (more negative or downward) than those measured at the surface by Holdsworth (1975). Further details of the calculations are given by Hudleston and Hooke (in press). We make use of the resulting strain field here.

The magnitudes and orientations of quantities describing cumulative strain and strain-rate are shown in Figure 8c. A convenient measure of strain magnitude is $\bar{\gamma}_{0}$, the natural octahedral unit shear (Nadai, I963, p. 73). In plane strain with no volume change this is given by:

$$
\bar{\gamma}_{0}=\frac{\sqrt{ } 6}{3} \ln R,
$$

where $R$ is the axial ratio of the strain ellipse (Hudleston and Hooke, in press).

The flow in our numerical model is two-dimensional and is very nearly one of no area change, although this was not a condition imposed on the velocity field used. Thus we use $\bar{\gamma}_{\mathrm{oc}}$ as defined in Equation ( $\mathrm{I}$ ) as our measure of cumulative strain magnitude, adding an

A

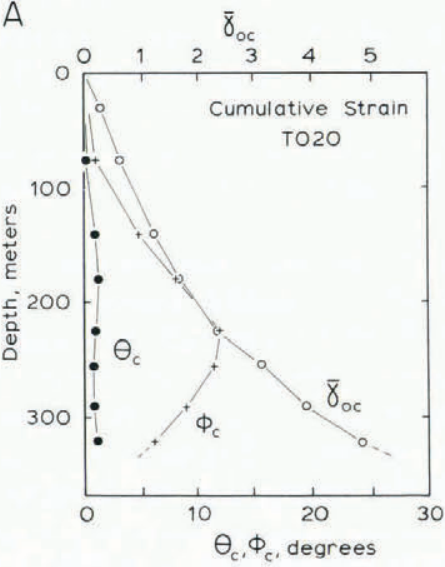

B

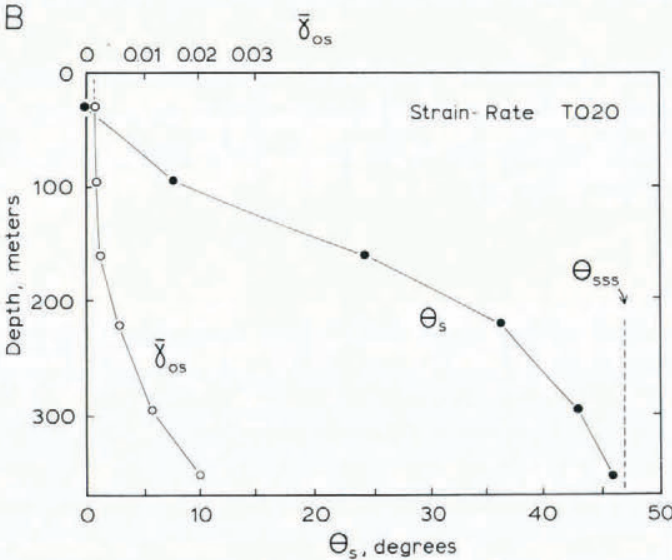

C

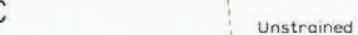

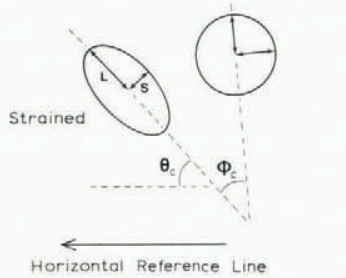

$\Phi$. = Rotation of line becoming principal axis in strained state

$\boldsymbol{\theta}_{c}=$ Orientation of greatest principal axis

$\bar{\gamma}_{\alpha<}=\frac{\sqrt{6}}{3} \ln \left(\frac{L}{5}\right)$ 
extra subscript to denote "cumulative". It should be noted, however, that this is not strictly the $\bar{\gamma}_{\mathrm{o}}$ of Nadai ( $\mathrm{r}^{6} 6_{3}$ ) because transverse strains, although small, are not zero. $\bar{\gamma}_{\text {oc }}$ is zero at the surface in the accumulation zone (Fig. 8a), non-zero at the surface in the ablation zone (Fig. 9a), and everywhere increases rapidly with depth.
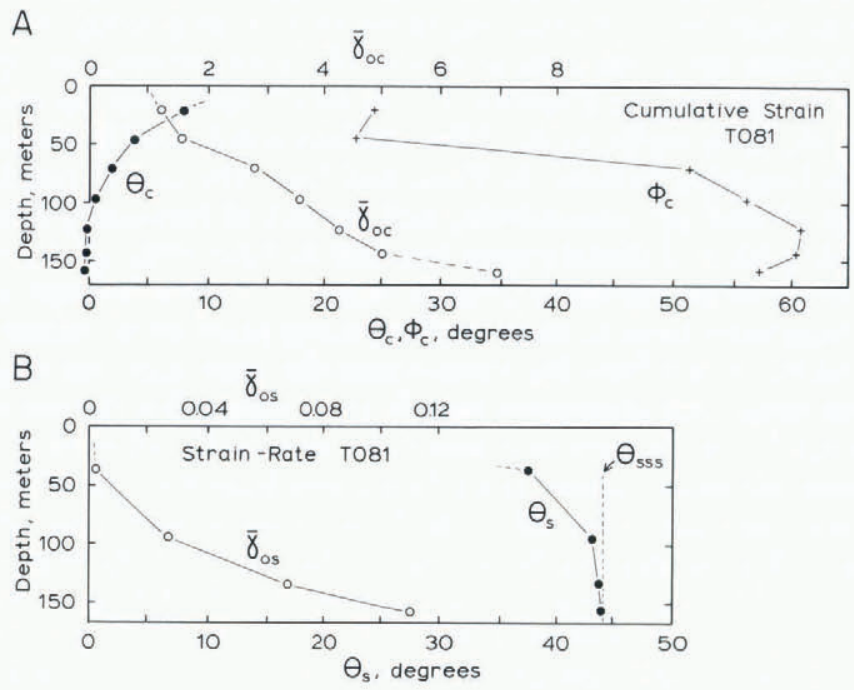

Fig. 9. (a) Cumulative strain parameters in bore hole To8I. (b) Strain-rate parameters for To8I. Symbols same as in Figure 8.

A quantity similar to $\bar{\gamma}_{\text {oc }}$ can be derived for strain-rate magnitude, such that

$$
\bar{\gamma}_{\mathrm{os}}=\frac{\sqrt{ } 6}{3} \ln \dot{R},
$$

where $\dot{R}$ is the axial ratio of the strain ellipse developed in a unit time (one year). $\bar{\gamma}_{\text {os }}$ increases with depth in a manner similar to $\bar{\gamma}_{\text {oc }}$ (Figs $8 \mathrm{~b}$ and $9 \mathrm{~b}$ ), but it does not vanish at the surface in either To2o or To8I ; its value at the surface reflects the longitudinal strain-rate.

The orientation of the greatest principal axis of the cumulative strain ellipse is given by $\theta_{\mathrm{c}}$. This angle is everywhere small and does not change much with depth (Figs $8 \mathrm{a}$ and $9 \mathrm{a})$. It is greatest near the surface in To8I (Fig. 9a). The corresponding angle for the strain-rate $\theta_{\mathrm{s}}$, shows a much greater variation with depth (Figs $8 \mathrm{~b}$ and $9 \mathrm{~b}$ ). In both To2o and To8 $\mathrm{I}$ it varies from $0^{\circ}$ at the surface to nearly $45^{\circ}$ at the bed.

The final quantity used to record cumulative strain is $\phi_{\mathrm{c}}$, the rotation of the line which becomes the principal axis at any stage of the deformation. With increasing depth $\phi_{\mathrm{c}}$ increases to a maximum and then decreases continuously towards the bed (Figs 8a and 9a).

We can consider deformation in the flow plane in terms of a continuum between pure shear and simple shear (e.g. Ramsay, I967, p. 56). Where the rotational component of the flow is zero, an instantaneous state of pure shear exists (still assuming no volume change and zero transverse strain-rate). If this condition persists through time for a given particle of material the principal axes of the cumulative strain will coincide with those of the strain rate $\left(\theta_{\mathrm{c}}=\theta_{\mathrm{s}}\right)$, and the strain will accumulate coaxially. In progressive simple shear, $\theta_{\mathrm{s}}$ is constant at $45^{\circ}$ to the shear plane, and $\theta_{\mathrm{c}}$ decreases systematically from $45^{\circ}$ initially towards $0^{\circ}$ as the strain magnitude grows towards infinity. Simultaneously, $\phi_{\mathrm{c}}$ increases from $0^{\circ}$ towards $90^{\circ}$ (Ramsay, I 967 , p. $83-88)$. 
The fact that the strain does not accumulate coaxially in the flow plane of the ice cap is shown both by the discrepancy between $\theta_{\mathrm{s}}$ and $\theta_{\mathrm{c}}$ (compare Figs $8 \mathrm{a}$ with $8 \mathrm{~b}$ and $9 \mathrm{a}$ with $9 \mathrm{~b}$ ), and by the value of $\phi_{c}$. In fact, the principal directions of the strain-rate tensor in the lower $30 \mathrm{~m}$ of To2o and lower $90 \mathrm{~m}$ of To8 $\mathrm{I}$ are within $2^{\circ}$ of the orientation (approximately $45^{\circ}$ ), predicted for simple shear $\left(\theta_{\mathrm{sss}}\right.$ in Figs $8 \mathrm{~b}$ and $\mathrm{gb}$ ). However, the cumulative rotation $\phi_{\mathrm{c}}$ in these lower regions is much less than that expected for a history solely of simple shear. To show this, we can calculate the component of rotation for a simple shear of a given magnitude, say $\bar{\gamma}_{\mathrm{oc}}=3.75$. To do this we use Equation (I) to find $R$ and then use standard equations (e.g. Ramsay, 1967 , ch. 3) to arrive at $\phi_{\mathrm{c}}$. This rotation is $80^{\circ}$, and increases towards $90^{\circ}$ as the strain magnitude increases further. In To2o and To8 $\mathrm{I}$ the actual rotations at this same strain magnitude are $9^{\circ}$ and $57^{\circ}$ respectively, and instead of increasing continuously as $\bar{\gamma}_{\text {oc }}$ increases, the rotations peak and then decrease towards the base of the glacier where the strainrate field is closest to one of simple shear (Figs $8 \mathrm{a}$ and 9a). This is because all particle paths that intersect these bore holes have an early stage of nearly pure shear (Hooke and Hudleston, 1978, fig. 3), and the lower the flow line intersecting the bore hole, the longer is this stage. The amounts of pure shear and subsequent simple shear determine the net rotation, and the nature of this two-stage history is such as to cause the peak in the plots of $\phi_{\mathrm{c}}$ with depth.

We can summarize the strain history of ice in the two bore holes as follows. In the upper part of To2o both strain-rate and cumulative strain are close to pure shear $\left(\theta_{\mathrm{s}} \approx \theta_{\mathrm{c}} \approx 0\right.$, and $\phi_{\mathrm{e}}$ is small, Fig. 8a). With increasing depth the strain-rate changes smoothly to approach simple shear at the base $\left(\theta_{\mathrm{s}} \rightarrow 47^{\circ}\right.$, Fig. $\left.8 \mathrm{~b}\right)$, but the cumulative strain continues to show the effects of a large amount of approximately pure shear $\left(\phi_{\mathrm{c}} \leqslant \mathrm{I} 2^{\circ}\right)$. In To8 $\mathrm{I}$, the strain-rate field approximates simple shear through much of the ice $\left(\theta_{\mathrm{s}}>4 \mathrm{I}^{\circ}\right.$ below $75 \mathrm{~m}$ depth, Fig. $9 \mathrm{~b})$, and the cumulative strain now shows a dominant influence of simple shear $\left(\phi_{\mathrm{c}}>50^{\circ}\right.$ below $70 \mathrm{~m}$, Fig. 9a), following a long history of flow under the influence of simple shear.

The main source of error in the quantities graphed in Figures 8 and 9 and discussed above arises from uncertainty in the reliability of the cumulative strain field due to uncertainty in the present velocity field and its changes through time (Hudleston and Hooke, in press). It is very difficult to assess the error involved, but the probable error will increase with depth and with distance along a flow line as older ice is encountered. Thus strain quantities in Figure $8 \mathrm{a}$ are more reliable, on the average, than those in Figure 9a. Our strain modeling suggests that by varying the steady-state velocity field within reasonable limits, based upon different ways of utilizing the observed velocity and mass-balance data, and by not allowing for significant advance or retreat of the ice cap in the past 2000 years (Hudleston and Hooke, in press), the values of $\bar{\gamma}_{\text {oc }}$ will not vary by more than about $20 \%$ of those plotted in Figures $8 \mathrm{a}$ and $9 \mathrm{a}$. In discussing the fabric patterns and their transitions, we are not greatly concerned with ice older than 2000 years.

\section{INTERPRETATION}

We are now in a position to relate observed fabrics to cumulative strain and strain path.

\section{Cumulative strain}

The magnitudes of the cumulative strains at which key fabric changes take place are shown in Table I. The change from a weakly-oriented to a small-circle pattern in To2o, and from a weakly-oriented to a broad single-maximum pattern in To6 $\mathrm{I}$ and To8 $\mathrm{I}$ occur at $\bar{\gamma}_{\mathrm{oc}}=\mathrm{I.2}$, I.o, and I.4 respectively. The values of $\bar{\gamma}_{\text {oc }}$ corresponding to the changes from elongate single-maximum to multiple-maximum fabrics in To20, To6 I, and To8 1 are 2.1, 2.7, and 3.6. Cumulative strains for the upper single-maximum fabrics in the white ice cannot be estimated reliably due to the viscosity contrast between it and the overlying blue ice and due to its much greater age. 
Table I. Strain values at transitions from One fabric Pattern to another

\begin{tabular}{|c|c|c|c|c|c|c|}
\hline \multirow{2}{*}{$\begin{array}{l}\text { Bore hole } \\
\quad \text { or } \\
\text { surface } \\
\text { positions }\end{array}$} & \multicolumn{3}{|c|}{$\begin{array}{c}\text { Weakly-oriented to lower } \\
\text { single-maximum or small-circle } \\
\text { fabric }\end{array}$} & \multicolumn{3}{|c|}{$\begin{array}{l}\text { Lower single-maximum or } \\
\text { small-circle to multiple- } \\
\text { maximum fabric }\end{array}$} \\
\hline & $\bar{\gamma}_{\mathrm{oc}}$ & $R$ & $\bar{\gamma}_{\mathrm{os}}$ & $\bar{\gamma}_{\mathrm{oc}}$ & $R$ & $\bar{\gamma}_{\mathrm{os}}$ \\
\hline To20 & $1.2 \pm 0.2^{*}$ & $4 \cdot 4$ & 0.002 & $2.1 \pm 0.3^{*}$ & 13 & 0.005 \\
\hline To6 I & $1.0 \pm 0.2$ & 3.4 & 0.005 & $2.7 \pm 0.3$ & 21 & 0.022 \\
\hline To8I & $1.4 \pm 0.2$ & 5.6 & 0.002 & $3.6 \pm 0.4$ & 82 & 0.032 \\
\hline $\begin{array}{l}\text { 086o } \\
0940\end{array}$ & I. 4 & $5 \cdot 5$ & & 3.4 & 64 & \\
\hline
\end{tabular}

* Uncertainties based on values of quantity $15 \mathrm{~m}$ above and below estimated depths of transitions.

For comparison, Hudleston (1977) found single-maximum fabrics developing at $\bar{\gamma}_{\mathrm{oc}} \approx 0.8$ in small shear zones near the edge of the ice cap. In the centers of these shear zones cumulative strains of $c .3 .0$ are attained, suggesting that multiple-maximum fabrics might be expected, although they have not been found.

Considering the gradational character of the fabric transitions and the uncertainties in the strain modeling, we feel that this agreement among the values of $\bar{\gamma}_{\mathrm{oc}}$ for the transition to single-maximum or small-circle fabrics is satisfactory. However, that for the transition to multiple-maximum fabrics is not, suggesting that other factors may play a role. The differences seem too large to be accounted for by errors in $\bar{\gamma}_{\text {oc }}$, particularly in view of the fact that errors in the velocity field would tend to affect all values of $\bar{\gamma}_{\mathrm{oc}}$ in the same direction.

\section{Strain path}

The influence of strain path is best illustrated by the differences in fabric pattern encountered below the weakly-oriented fabric zone (Fig. 2). In To2o the pattern is a small circle (Fig. 3) but in To6 $\mathrm{I}$ and To8 $\mathrm{I}$ it is a broad single maximum (Fig. 4). Following a particle path from To8r we find that further down-glacier this broad single maximum changes back to a small circle at 0875 (Fig. 4).

Laboratory and field studies have shown that broad single-maximum fabrics develop under simple shear (Steinemann, I958; Kamb, I959; Hudleston, 1977), two-pole fabrics with poles between the greatest and least principal strain axes develop in pure shear (Schwarzacher and Untersteiner, 1953; Untersteiner, 1954; Vallon, 1967), and small-circle fabrics form under uniaxial compression (Budd, I972; Kamb, 1972). It is inferred in these cases that due to recrystallization and/or rotation, the basal planes of ice crystals come to lie preferentially in the direction of maximum shearing stress.

Although the strain modeling suggests that pure shear dominates near the surface of the glacier, it should be recalled that the modeling did not take transverse strains into account. Holdsworth (1975) found that $\dot{e}_{x x}=0.00 \mathrm{I} \mathrm{I} \mathrm{a}^{-1}$ and $\dot{e}_{y y}=0.000 \mathrm{I} \mathrm{a}^{-1}$ at the surface near To2o (where $x$ is longitudinal and $y$ transverse). About $0.5 \mathrm{~km}$ up-glacier from To2o $\dot{e}_{x x}$ is still about o.0oI I a ${ }^{-1}$ but $\dot{e}_{y y}$ approaches zero. These rates may vary with depth, of course, so we do not know if $\dot{e}_{y y}$ is larger along the particle path leading to I $50 \mathrm{~m}$ in To2o; however, we infer from the fabric pattern that the ice there has been subjected to sufficiently large transverse strains to develop what appears to be a small-circle fabric rather than the twomaximum pattern anticipated for pure shear.

In ice with comparable cumulative strains further down-glacier, the pure shear component of the strain decreases and the simple shear component increases (Figs 8 and 9). This is inferred to be responsible for the single-maximum fabrics in To6 I and To8I. Still further down-glacier, however, as the ice approaches the surface, the pure shear component again 
increases. At 0875 Holdsworth (1975) shows $\dot{e}_{x x}=-0.0006$ and $\dot{e}_{y y}=-0.0004$, corresponding to a situation of uniaxial extension about a vertical axis. Kamb (1972, fig. I8) has suggested that this should give rise to another small-circle fabric but at a larger angle to the extension axis. This, in fact, is observed; at 0875 (Fig. 4) the angle is $39^{\circ}$, in comparison with $33^{\circ}$ at To2o. As the ice of 0875 is on the same particle path as that showing a single-maximum fabric in To8 $\mathrm{I}$, the uniaxial strain in the most distal part of the particle path apparently has been sufficient to modify the single-maximum pattern developed previously.

Except near the surface, the strain path experienced by ice along most of the flow line is very nearly one of progressive simple shear (Hudleston and Hooke, in press). In nearly all the fabric diagrams in Figures 2-4 there are high concentrations of $c$-axes within $20^{\circ}$ of vertical, corresponding to basal planes lying at low angles to the "shear plane". Thus it seems likely that whatever the reasons for the differences among the fabric patterns, basal glide is an important mechanism affecting the fabric in all cases.

\section{Discussion}

One objective of studies such as this is to be able to predict the distribution of various fabrics and textures in a flow plane on the basis of detailed understanding of the relevant independent variables. The fact that the independent and dependent variables have not yet been clearly identified illustrates the present state of the art.

Rigsby (1958, 1960) called attention to the importance of strain-rate, and to the relation between cell size and fabric. Kamb (1959, 1972) mentioned the importance of stress and cumulative strain. Budd (1972) added strain path to the list of variables, and also brought up the possibility of mechanical rotation of crystals. Hooke's work (1973) pointed to the significance of high concentrations of air bubbles and Gow and Williamson (1976) suggested that particulate matter, in their case volcanic dust, might play a role. C. F. Raymond (written communication in May 1979) observes that the initial fabric would also be important. As a start we will consider temperature, stress, and cumulative strain, as the most likely independent variables, as the initial fabric is probably weakly oriented in all cases. We further assume that texture and fabric are both dependent on these three variables, although it may well be that fabric is, at least in part, dependent on texture.

We will concentrate primarily on fabric and will discuss, in particular, four fabric types developed in simple shear; weakly oriented, low strain-rate (lower) single maximum, multiple maximum, and high strain-rate (upper) single maximum. Small-circle fabrics are viewed as a variety of lower single-maximum fabric formed under conditions of uniaxial compression, and two-pole fabrics with poles in appropriate positions are a variety formed in pure shear.

The basic known relationships can be summarized as follows:

(I) In the Barnes Ice Cap the distribution of the four principal fabrics is shown in Figure 2b. The sharp single maximum in the white ice is the upper single maximum while the broad single maximum higher in the glacier in the lower single maximum.

(2) In the Byrd core Gow and Williamson (1976) find a similar progression with depth from a weakly-oriented fabric at the surface to a lower single-maximum fabric (small-circle variety) at a depth of about $400 \mathrm{~m}$, and thence to a double-maximum fabric at $\mathrm{I} 000 \mathrm{~m}$. The transition to upper single-maximum fabrics occurs at about I $200 \mathrm{~m}$. In contrast to the situation in the Barnes Ice Cap, however, there is a transition back to a multiple-maximum fabric in the Byrd core at a depth of about r $830 \mathrm{~m}$. Matsuda and others (1976) and W. F. Budd (written communication in July 1977) report a similar sequence of changes with depth in the Law Dome, Antarctica.

(3) The fabrics observed by Kamb (1959) in bands of fine ice in the Blue Glacier were probably lower single-maximum fabrics. Kamb thought this ice might have been subjected to high strain-rates for an appreciable length of time, but oxygen-isotope studies (Sharp and 
others, 1960) suggest that many of the bands are crevasse fillings formed locally, and thus have low cumulative strains.

(4) Kamb (1972) found a double-maximum pattern at cumulative strains between o.I and 0.3 in his laboratory experiments. The stronger of the maxima coincides with our broad single-maximum, and the weaker is at $c .120^{\circ}$ to this, in the direction of shear. Hudleston ( 1977 ) found a similar double-maximum pattern at cumulative strains up to $c$. 0.8 in small shear zones near the margin of the ice cap. At higher strains the weaker maximum disappears.

(5) Multiple-maximum fabrics apparently do not form readily in ice appreciably colder than $-10^{\circ} \mathrm{C}$. We do not consider the fabrics with maxima of only $5 \%$ of the points in one per cent of the net area found in fine ice near the top of the Byrd core at temperatures of about $-30^{\circ} \mathrm{C}$ (Gow and Williamson, r 976) to be equivalent to our multiple-maximum fabrics, which typically have individual maxima in excess to $20 \%$ and much larger crystal sizes. Watanabe and Ōra (I968) also describe some of these weak multiple-maximum fabrics developed during laboratory tests in uniaxial compression. Our impression is that these maxima are local concentrations of $c$-axes in small-circle fabrics, and have no statistical significance.

(6) Multiple maximum fabrics may be a result of crystallographic twinning (Matsuda and others, 1976). Some materials are known to deform almost exclusively by twinning, but in contrast to ice the twins in such materials are in the form of alternating twin lamellae (Venables, I964; Bolling and Richman, 1965). Furthermore an increase in temperature seems to inhibit, rather than promote such twinning (Bolling and Richman, I965).

(7) There may well be an instability involved in at least some of the transitions from one fabric to another. Hudleston (1977), for example, found shear zones, a few centimeters thick, in the wedge of deformed superimposed ice formed at the margin of the Barnes Ice Cap. Distinct single-maximum fabrics and coarser grain sizes were found inside the shear zones, in contrast to the weakly-oriented fabrics outside. It appears that once a zone of weakness develops, recrystallization and formation of the single-maximum fabric increases the strainrate and promotes further recrystallization. The shear zone thus expands. A similar instability at the transition from the lower single-maximum to the multiple-maximum fabric may account for the fact that bands of ice with single-maximum fabrics 2 to $5 \mathrm{~m}$ thick alternate with similar bands having multiple-maximum fabrics in deformed superimposed ice that has undergone greater cumulative strain (Hooke, 1973).

If we are correct in our suggestion that temperature $T$, stress $\tau$, and cumulative strain $\bar{\gamma}_{\text {oc }}$ are the primary independent variables, it should be possible to plot a stability diagram showing which fabrics are stable under conditions of simple shear in $T-\tau-\bar{\gamma}_{\text {oc }}$ space. The least wellknown of these variables is $\bar{\gamma}_{\text {oc }}$, so initially we plot $T$ against $\tau$ and record our estimate of $\bar{\gamma}_{\text {oc }}$ (Table I) numerically beside the points (Fig. Io). $\tau$ is approximated by $\rho g h \sin \alpha$ where $\alpha$ is the surface slope in the vicinity of the respective bore holes, $h$ is the depth to a given transition between fabric types, and $\rho$ and $g$ have their usual meanings. $T$ is obtained from measurements in the bore holes.

In addition to the data from the Barnes Ice Cap, we have also plotted fabric transitions in the Byrd bore hole from Gow and Williamson (1976). In calculating $\tau$, the ice surface slope at Byrd Station, o.oo I 6I, was obtained from Robin ([1970], p. I45), and an ice density of $0.9 \mathrm{Mg} / \mathrm{m}^{3}$ was used, thus ignoring the effect of lower-density firn at the surface. Values of $\bar{\gamma}_{\mathrm{oc}}$ are not available for the transitions in the Byrd core, but we presume that they are much larger than those for the transitions in the Barnes Ice Cap.

The double-maximum pattern of Kamb (1972) is distinct from the two-maximum fabrics formed in the multiple-maximum field of Figure ro. In the former a line joining the two maxima is parallel to the direction of shear, whereas in the latter it is perpendicular to the direction of shear. Kamb's double-maximum pattern occupies a narrow range of $\bar{\gamma}_{\text {oc }}$ between the weakly-oriented and lower single-maximum fields of Figure ro and is not shown. 
The relation between $\bar{\gamma}_{\mathrm{oc}}$ and $\tau$ in Figure so is not clear. The multiple-maximum fabrics that occur at very low stresses and temperatures in the Byrd bore hole seem inconsistent with the multiple-maximum field defined by the Barnes Ice Cap data, and it is tempting to attribute this to the much higher cumulative strains inferred for the Byrd Station ice. However, at lower stresses the transitions from lower single-maximum to multiple-maximum fabrics in the Barnes Ice Cap occur at lower cumulative strain (Fig. Io). We thus infer that the higher temperatures at these lower stresses are responsible for reducing the cumulative strain required for the transition.

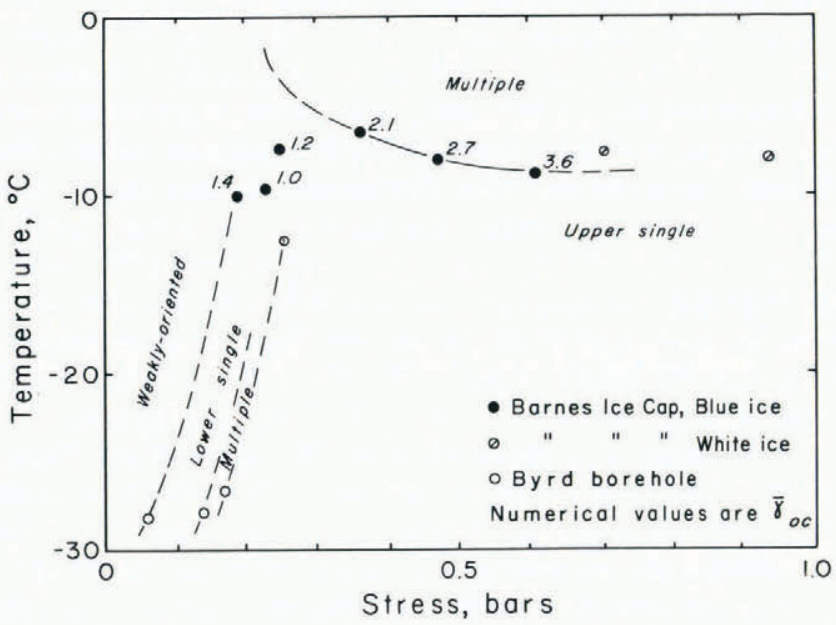

Fig. 10. Stability diagram for various fabrics developed in simple shear in $T-\tau$ space with $\bar{\gamma}_{\mathrm{oc}}$ indicated numerically where known. Points with $\bar{\gamma}_{\mathrm{oc}}<1.5$ are for transition from weakly-oriented to lower single-maximum fabrics. Points with $\bar{\gamma}_{\mathrm{oc}}>2$ are for transition from lower single-maximum to multiple-maximum fabrics. Lines are projected onto plane of diagram from third dimension, $\bar{\gamma}_{\mathrm{oc}}$. Thus $\bar{\gamma}_{\mathrm{oc}}$ varies along lines.

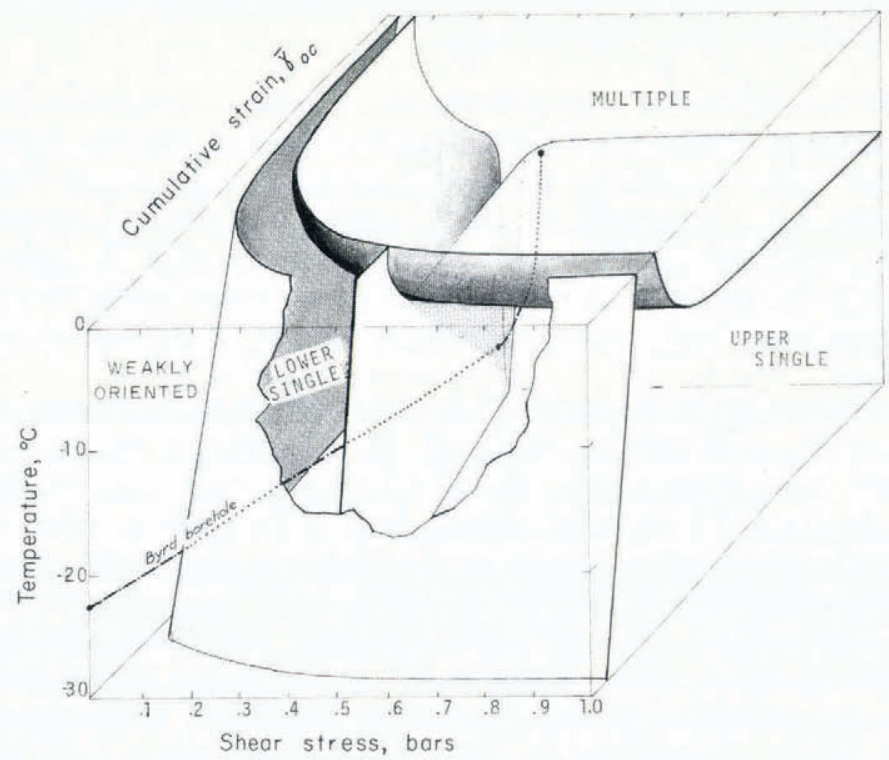

Fig. II. Schematic stability diagram for various fabrics developed in simple shear in $T-\tau-\bar{\gamma}_{\mathrm{oc}}$ space. Scales on axes are approximate. Drawn by $R$. Venkatakrishnan. 
To depict this more graphically we present in Figure i I a schematic three-dimensional sketch of $T-\tau-\bar{\gamma}_{\text {oc }}$ space. The stability fields shown in this figure are consistent with the known relations discussed earlier. In addition, by making the transition between weakly-oriented and lower single-maximum fabrics asymptotic to a low but finite stress at high cumulative strain, we suggest that preferred-orientation fabrics may not develop at stresses that are too low for recovery creep, where deformation is by diffusive processes alone.

Also plotted in Figure $\mathrm{I}$ I is an inferred path in $T-\tau-\bar{\gamma}_{\mathrm{oc}}$ space for the Byrd bore hole, showing how the stability field for multiple-maximum fabrics is intersected twice in the bore hole.

Implicit in the construction of Figures ro and I I are two assumptions. First, we assume that the deformation is predominantly simple shear so strain path need not be considered in estimating cumulative strain. Secondly, we assume that strain-rate need not be considered separately. Strain-rate is a function of stress, temperature, fabric, ice density, and the concentration of impurities. To consider it as one of our independent variables might be advantageous as it would incorporate many of these other variables into a single parameter. However strain-rates are difficult to estimate accurately due to the uncertainty in the constants which one must use in any constitutive relation between strain-rate and the other parameters listed. Furthermore strain-rate is not independent of temperature and fabric, so there would be redundancy in a $T-\dot{\epsilon}-\bar{\gamma}_{\mathrm{oc}}$ diagram, for example.

\section{Concluding statement}

We view Figure I I as a first attempt at synthesizing the large amount of available data on fabrics in glacier ice. Systematic relations are clearly present; a given fabric is apparently stable only under a certain range of conditions. Thus in principle it is possible to specify the stable fabric for any given combination of the independent variables. The problem is one of first identifying the independent variables, and then determining the range of conditions, expressed in terms of these variables, under which any given fabric is stable.

We have suggested that temperature, stress, and cumulative strain are three possible independent variables, and found that the stability fields of the various fabric patterns can be expressed in terms of these variables if other possible ones, such as ice density and impurity content, are constant. More field data and theoretical studies are necessary to determine whether these variables will suffice and to establish the stability fields more accurately.

\section{Acknowledgements}

This research was supported financially by the U.S. National Science Foundation (Grants EAR 74-12293, EAR 77-21098, and EAR 77-12990) and logistically by the Glaciology Division, Environment Canada. We thank G. H. Holdsworth for use of facilities at the Glaciology Division Camp on the Barnes Ice Cap and for his assistance in obtaining permission for us to do the work. The critical comments of C. F. Raymond significantly improved the paper. B. Koci drilled hole To2o, assisted in drilling the other holes, and did some of the fabric analyses from To8r.

MS. received 13 March 1979 and in revised form 29 May 1979

\section{REFERENCES}

Bolling, G. F., and Richman, R. H. 1965. Continual mechanical twinning. Parts 1-4. Acta Metallurgica, Vol. 13, No. 7, p. 709-57.

Budd, W. F. 1972. The development of crystal orientation fabrics in moving ice. Zeitschrift für Gletscherkunde und Glazialgeologie, Bd. 8, Ht. I-2, p. $65^{-105}$.

Gow, A. J., and Williamson, T. 1976. Rheological implications of the internal structure and crystal fabrics of the West Antarctic ice sheet as revealed by deep core drilling at Byrd Station. Geological Society of America. Bulletin, Vol. 87, No. 12, p. 1665-77.

Hobbs, B. E., and others. 1976. An outline of structural geology, by B. E. Hobbs, W. D. Means, and P. F. Williams. New York, John Wiley and Sons, Inc. 
Holdsworth, G. H. 1975. Deformation and flow of Barnes Ice Cap, Baffin Island. Ottawa, Environment Canada. Inland Waters Directorate. Water Resources Branch. (Scientific Series, No. 52.)

Hooke, R. L. 1969. Crystal shape in polar glaciers and the philosophy of ice-fabric diagrams. Fournal of Glaciology, Vol. 8, No. 53, p. 324-26. [Letter.]

Hooke, R. L. 1973. Structure and flow in the margin of the Barnes Ice Cap, Baffin Island, N.W.T., Canada. Journal of Glaciology, Vol. 12, No. 66, p. 423-38.

Hooke, R. L. [ $\left.{ }^{\mathrm{c}} \mathrm{I} 976.\right]$ University of Minnesota ice drill. (In Splettstoesser, J. F., ed. Ice-core drilling. Proceedings of a symposium, University of Nebraska, Lincoln, 28-30 August 1974. Lincoln, London, University of Nebraska Press, p. 47-57.)

Hooke, R. L. 1976. Pleistocene ice at the base of the Barnes Ice Cap, Baffin Island, N.W.T., Canada. Journal of Glaciology, Vol. 17, No. 75, p. 49-59.

Hooke, R. L., and Hudleston, P. J. 1978. Origin of foliation in glaciers. Fournal of Glaciology, Vol. 20, No. 83, p. 285-99.

Hudleston, P. J. 1977. Progressive deformation and development of fabric across zones of shear in glacial ice. (In Saxena, S., and Bhattacharji, S., ed. Energetics of geological processes. New York, Springer-Verlag, p. I 2 I-50.)

Hudleston, P. J., and Hooke, R. L. In press. Cumulative deformation in glaciers and implications for the development of foliation. Tectonophysics.

Jones, S. J. 1972. Radio depth-sounding on Meighen and Barnes Ice Caps, Arctic Canada. Ottawa, Environment Canada. Inland Waters Directorate. Water Resources Branch. (Scientific Series, No. 25.)

$\mathrm{Kamb}$, W. B. 1959. Ice petrofabric observations from Blue Glacier, Washington, in relation to theory and experiment. Fournal of Geophysical Research, Vol. 64, No. I1, p. 1891-909.

Kamb, W. B. I 962 . Refraction corrections for universal stage measurements. I. Uniaxial crystals. American Mineralogist, Vol. 47, No. 3, p. 227-45.

Kamb, W. B. I972. Experimental recrystallization of ice under stress. (In Heard, H. C., and others, ed. Flow and fracture of rocks, edited by H. C. Heard, I. Y. Borg, N. L. Carter, and C. B. Raleigh. Washington, D.C., American Geophysical Union, p. 2 I I-41. (Geophysical Monograph i6.))

Kellerhals, R., and others. 1975. On grain size from thin sections, by R. Kellerhals, J. Shaw, and V. K. Arora. Fournal of Geology, Vol. 83, No. I, p. 79-96.

Krumbein, W. C. 1935. Thin-section mechanical analysis of indurated sediments. Journal of Geology, Vol. 43, No. 5 , p. $482-96$.

Langway, C. C., jr. 1958. Ice fabrics and the universal stage. U.S. Snow, Ice and Permafrost Research Establishment. Technical Report 62.

Matsuda, M., and oîhers. I976. Nankyoku hyōshō-hyō no sōshō. Hyō-kesshō a-jiku no sokutei ni motozuku daiyamondopatān no keisei ni tsuite [Twinning of ice from Antarctic ice sheet. Observations of $a$-axis orientation associated with diamond $c$-axis orientation fabric]. [By] M. Matsuda, G. Wakahama, W. F. Budd. Teion-kagaku: Low Temperature Science, Ser. A, [No.] 34, p. 163-71.

Nadai, A. 1963 . Theory of flow and fracture of solids. Vol. 2. New York, McGraw-Hill Book Co., Inc. (Engineering Societies Monographs.)

Ramsay, J. G. 1967. Folding and fracturing of rocks. New York, McGraw-Hill Book Co., Inc.

Rigsby, G. P. 1958. Fabrics of glacier and laboratory deformed ice. Union Géodésique et Géophysique Internationale. Association Internationale d'Hydrologie Scientifique. Symposium de Chamonix, 16-24 sept. 1958, p. 351-58. (Publication No. 47 de l'Association Internationale d'Hydrologie Scientifique.)

Rigsby, G. P. I96o. Crystal orientation in glacier and in experimentally deformed ice. Fournal of Glaciology, Vol. 3 , No. 27 , p. 589-6o6.

Robin, G. de Q. [1970.] Stability of ice sheets as deduced from deep temperature gradients. [Union Géodésique et Géophysique Internationale. Association Internationale d'Hydrologie Scientifique.] [International Council of Scientific Unions. Scientific Committee on Antarctic Research. International Association of Scientific Hydrology. Commission of Snow and Ice.] International Symposium on Antarctic Glaciological Exploration (ISAGE), Hanover, New Hampshire, U.S.A., 3-7 September 1968, p. 141-51. [(Publication No. 86 [de l'Association Internationale d'Hydrologie Scientifique].)]

Schwarzacher, W., and Untersteiner, N. 1953. Zum Problem der Bänderung des Gletschereises. Sitzungsberichte der Österreichischen Akademie der Wissenschaften. Mathematisch- naturwissenschaftliche Klasse, Abt. 2A, Bd. I62, Ht. $\mathrm{I}-4$, p. I I $\mathrm{I}-45$.

Sharp, R. P., and others. 1960. Oxygen-isotope ratios in the Blue Glacier, Olympic Mountains, Washington, U.S.A., [by] R. P. Sharp, S. Epstein, and I. Vidziunas. Journal of Geophysical Research, Vol. 65, No. 12,

p. 4043-59.
Smith, C. S., and Guttman, L. 1953. Measurement of internal boundaries in three-dimensional structures by random sectioning. Fournal of Metals, Vol. 5 , No. 1, p. $8 \mathrm{I}-87$.

Steinemann, S. 1958. Experimentelle Untersuchungen zur Plastizität von Eis. Beiträge zur Geologie der Schweiz. Geotechnische Serie. Hydrologie, Nr. 10.

Untersteiner, N. r954. Über die Feinbänderung und Bewegung des Gletschereises. Archiv für Meteorologie, Geophysik und Bioklimatologie, Ser. A, Bd. 7, p. $23 \mathrm{I}-42$.

Venables, J. A. 1964. The electron microscopy of deformation twinning. Fournal of the Physics and Chemistry of Solids, Vol. 25 , No. 7 , p. $683-92$.

Vallon, M. I967. Étude de la Mer de Glace, 2ème partie: pétrographie du névé et de la glace, structure du glacier. Rapport Scientifique du Laboratoire de Géophysique et Glaciologie de Grenoble, No. I03.

Watanabe, O., and Ōura, H. I968. Hen atsu ni yoru kōri kesshō shujiku no teihōisei ni tsuite no jikkenteki kenkyū. I [Experimental studies of preferred orientation of polycrystalline ice by unconfined compression. I]. Teion-kagaku: Low Temperature Science, Ser. A, [No.] 26, p. 1-28. 